\title{
Impact of Food based Supplementation on Iron Nutrition of School Children
}

\author{
Rita Singh Raghuvanshi ${ }^{*}$, Pushpa Shukla ${ }^{1}$ and Rashmi Singh ${ }^{2}$ \\ ${ }^{1}$ Department of Foods and Nutrition, College of Home Science, G.B. Pant University of \\ Agriculture and Technology, Pantnagar, Uttarakhand, India \\ ${ }^{2}$ Department of Foods and Nutrition, College of Home Science, C.S.A. University of \\ Agriculture and Technology, Kanpur, Uttar Pradesh, India \\ *Corresponding author
}

\section{A B S T R A C T}

Keywords

Anemia,

Hemoglobin, Iron rich snacks, Green leaves powder, School children

\section{Article Info}

Accepted:

10 October 2020 Available Online: 10 November 2020
The objective of the study was to develop iron rich snacks by using dried green leaves powder and to evaluate the effect of their supplementation on iron status of 7-12 year old school children. Prevalence of anemia in school children $(\mathrm{n}=421)$ was found to be $88.59 \%$. The anemic group received two iron rich snacks on alternate days for 100 days. The iron content in Swadisht chikki and chatpata namkeen mix with chutney was found to be 18.03 and $14.57 \mathrm{mg} / 100 \mathrm{~g}$ respectively. All the subjects received deworming tablets, albendazole before supplementation. After supplementation duration it was statistically found that hemoglobin was significantly higher and the incidence of severe and mild degree of anemia was significantly lower in the children who received supplementation.

\section{Introduction}

Anemia is the most prevalent nutritional disorder in the world. Children are particularly vulnerable to iron deficiency anemia because of their increased iron requirements in the periods of rapid growth (WHO 2008). Anemia affects the cognitive performance, behaviour and physical growth. It has a deteriorating effect on the immune status which leads to increased morbidity from a variety of causes including diarrhoea and acute respiratory infections (WHO 2001).
Iron deficiency linked to low nutritional iron consumption is one of the critical causes of childhood anemia in India (Pasricha et al., 2010).

Anaemia prevalence among children of school going age is $37.70 \%$, among nonpregnant women $35 \%$ and among adult males $18 \%$ (Kotecha et al., 2009). According to NFHS-3 (2005-2006) $79 \%$ of Indian children were anemic and were found more in rural areas. 
Iron and folic acid supplementation, food fortification with iron and other strategies like changing dietary habits, control of parasites and nutrition education are considered as effective interventions to control the anemia from a public health angle (Park, 2017).

Food-based approaches represent the most desirable and sustainable method of preventing micronutrient malnutrition. Such approaches are designed to increase micronutrient intake through the diet (WHO 2001). Schools are a practical platform to deliver an integrated package of interventions, such as nutritious meals or snacks, micronutrient supplements or on-site fortification, infection control, health promotion and life skills education, to improve the health and nutrition of school children (Best et al., 2010).

Non-haem iron contributes about 90-95 per cent of total daily iron in Indian diets with majority of Indians obtaining non-haem iron from cereals, pulses, vegetables and fruits (NNMB 2006). Considering the magnitude of anemia and vegetarian food preferences in the country, the present study aims at assessing the impact of intervention with iron rich snacks, administered on a daily basis to anemic school going children from 7 to 12 years, on the hemoglobin levels and nutritional status.

\section{Materials and Methods}

Development of iron rich snacks and sensory acceptability

The raw ingredients which were selected on the basis of pre-reported iron values by Gopalan, et al., (1995) were rice flakes, roasted Bengal gram, jaggery, mustard and spinach leaves powder for the development of iron rich snacks. Two products swadisht chikki (SC), and chatpata namkeen mix with chutney (CNMC) were developed using the selected raw ingredients. Then the products were evaluated for their sensory quality characteristics, nutrient composition and in vitro bioavailability of iron.

Swadisht chikki was prepared by sautéing $125 \mathrm{~g}$ rice flakes with $50 \mathrm{~g}$ roasted Bengal gram in fat till they become crispy. Water was boiled with jaggery till the hard ball stage sets in. Sautéed roasted Bengal gram, rice flakes and $12.5 \mathrm{~g}$ mustard leaf powder and $5 \mathrm{~g}$ spinach leaf powder were added in the syrup. Prepared mixture was spread over a greased plate. When set, chikki was cut into pieces and served for 5 plates.

Chatpata namkeen mix with chutney was prepared by sautéing $300 \mathrm{~g}$ rice flakes with $75 \mathrm{~g}$ roasted Bengal gram in fat till they become crispy. It was removed from the fire and salt, $12.5 \mathrm{~g}$ chat masala and $12.5 \mathrm{~g}$ mustard leaf powder was added.

Chutney was prepared by boiling $50 \mathrm{~g}$ jaggery in water. To this, $15 \mathrm{~g}$ spinach leaf powder, salt and $1 \mathrm{~g}$ citric acid was added. Chatpata namkeen mix was served with the chutney.

Sensory evaluation of the developed iron rich snacks was done using nine point hedonic scale.

\section{Estimation of nutrient composition in iron rich snacks}

The proximate composition of snacks was analyzed according to the method described by the Association of Official Analytical Chemists (AOAC 1995). Calcium was estimated according to AOAC (1975) and iron was estimated by Wong's method (Raghuramulu et al., 2003). All the soluble and ionizable iron in the samples was extracted by procedure given by Rao and Prabhavathi (1978) estimates were done in 
triplicate. Ionizable iron was determined according to AOAC (1975) while soluble iron was determined as described by Tennat and Greenman (1969).

\section{Study design}

The study was conducted in 3 primary schools of University campus, situated in the district Udham Singh Nagar of Uttarakhand, India. Three schools were selected from total eight schools in the region by purposive sampling. The children were supplemented and followed up for 100 days excluding Sunday, holidays and the day when child was absent in school. The study protocol was fully explained to the participants' parents, and informed signed consent was obtained from the parents of children.

\section{Participants}

In selected three primary schools there were total 552 students in the age group of 7-12 years. Out of the total students only 421 students/parents agreed to participate in the study. Eligibility criteria for inclusion in the study were as follows: willing to participate in the study, aged 7-12 years, no major illnesses, and the presence of mild to severe iron deficiency anemia (IDA). Exclusion criteria were as follows: not willing to participate in the study, known medical disorder or any other chronic disease affecting dietary intake and those taking iron folic acid tablets. Anemia is considered to be mild, moderate and severe when hemoglobin concentrations are 10-12 g/dl, 7-10 g/dl and 60 per cent or less than $7 \mathrm{~g} / \mathrm{dl}$ respectively (WHO 1989). The participants were classified on the basis of above explained hemoglobin concentration of $\geq 12 \mathrm{~g} / \mathrm{dl}$ to be non-anemic and $<12 \mathrm{~g} / \mathrm{dl}$ to be anemic.

Blood samples were obtained at baseline from 421 children aged 7-12 years. Eighty five children met the criteria mentioned above and form the anemic group and were selected for intervention while forty eight children were taken in non-anemic group.

Socio economic status: Information was collected by interviewing the mothers at home, regarding type of family, family size, per capita income and education of parents.

Hemoglobin estimation: The blood samples collected from the schools by the trained investigator were analyzed within 2 days of time period. $20 \mu \mathrm{l}$ of finger prick blood sample was collected using fixed volume Finn pipettes with disposable tip, by standard procedures, transferred into a test tube containing $5 \mathrm{ml}$ of Drabkin's reagent and left for 30 minutes. The hemoglobin was estimated using a photoelectric digital colorimeter at $540 \mathrm{~nm}$ using a green filter by cyanmethemoglobin method and recorded in g/dl (Raghuramulu et al., 2003).

\section{Supplementation Feeding}

Children who had hemoglobin levels $<12$ g/dl were fed with the formulated iron rich snacks viz. chatpata namkeen mix with chutney (CNMC) and swadisht chikki (SC). A daily serving of each snack consisted of $75 \mathrm{gm}$. The snacks were consumed 6 days/week at the mid-morning break with consumption directly monitored and recorded by the investigator. The snacks were packed into individual, plastic sachets containing a daily serving and were stored in opaque plastic containers at room temperature and were distributed on alternate days to the participating children in the anemic group.

Both the anemic or non-anemic groups, were treated initially with deworming tablets. Albendazole (400 mg) manufactured by Cadila Health Care Ltd., was prescribed by the local physician considering worm infestation in the area. 


\section{Statistical analysis}

The data was analyzed for percentage, mean, standard deviation and paired ' $t$ ' test was applied to find the significant difference amongst the groups in pre- and postintervention period (Snedecor and Cochran 1967).

\section{Results and Discussion}

\section{Sensory acceptability of the developed products}

Sensory evaluation on a nine point hedonic scale showed that both the products SC as well as CNMC were liked very much by the semi-trained panel as well as by the school children (Table 1).

\section{Determination of nutrient composition of the developed products}

The products developed namely CNMC and $\mathrm{SC}$ had moisture content ranging from 3.18 to 6.18 per cent. The snacks also consist of good quality protein derived from the cereal-pulse combination. Protein content in SC was 8.14 $\mathrm{g} / 100 \mathrm{~g}$ and in CNMC was $7.02 \mathrm{~g} / 100 \mathrm{~g}$. The products were high in energy content ranging between $413 \mathrm{kcal} / 100 \mathrm{~g}$ in CNM, 386 $\mathrm{kcal} / 100 \mathrm{~g}$ in $\mathrm{SC}$ and $359 \mathrm{kcal} / 100 \mathrm{~g}$ in CNMC (Table 2). The calcium content of the selected products was $160 \mathrm{mg} / 100 \mathrm{~g}$ in CNM, $112.5 \mathrm{mg} / 100 \mathrm{~g}$ in $\mathrm{SC}$ and $181 \mathrm{mg} / 100 \mathrm{~g}$ in CNMC. $25-40 \%$ of the daily requirement of calcium of school going children could be met by the consumption of $100 \mathrm{~g}$ of these snacks. The iron content in CNM, SC and CNMC was found to be $13.71,18.03$ and $14.57 \mathrm{mg} / 100 \mathrm{~g}$ respectively. The soluble iron and ionizable iron as well as the total iron contents were determined at $\mathrm{pH} 1.35$ and 7.5. At $\mathrm{pH} 1.35$, the soluble iron was slightly higher than the ionizable iron and when the $\mathrm{pH}$ was increased to 7.5 , both the ionizable iron and soluble iron decreased, although the decrease in ionizable iron was of greater magnitude. Ionizable iron at $\mathrm{pH} 7.5$ in CNM, CNMC and SC was 18.61, 23.36 and 16.49 per cent respectively in $100 \mathrm{~g}$ (Table 3). Results of in vitro iron availability revealed that in vitro availability of iron for CNMC and SC was more than CNM.

\section{Information on socioeconomic status}

Out of 133 families surveyed 85.7 per cent of the families were nuclear. Size of the families ranged from 4-10 members with 83.4 per cent families having more than five members. 71 per cent families had 3-5 children whereas 27 per cent families in the area had more than five children. 31 per cent families included in the study were below poverty line. Majority of the parents (41.3 per cent fathers and 73.6 per cent mothers) were illiterate. All the children belonged to the families of laborers working in the farm.

\section{Prevalence of anemia}

Anemia is considered to be mild, moderate and severe when hemoglobin concentrations are $10-12 \mathrm{~g} / \mathrm{dl}, 7-10 \mathrm{~g} / \mathrm{dl}$ and 60 per cent or less than $7 \mathrm{~g} / \mathrm{dl}$ respectively (WHO 1989). The participants were classified on the basis of above explained hemoglobin concentration of $\geq 12 \mathrm{~g} / \mathrm{dl}$ to be non-anemic and $<12 \mathrm{~g} / \mathrm{dl}$ to be anemic.

It was found that 88.59 per cent children were anemic out of which 47.72, 49.06 and 3.21 per cent had mild, moderate and severe degree of anemia, respectively. The prevalence of iron deficiency anemia was significantly higher in girls (56.06 per cent) than in boys (43.92 per cent) as shown in Table 4.

Moderate anemia 61.17 per cent was most common in both the age groups, whereas the percentage of children having mild and severe anemia were 34.11 per cent and 4.70 per cent respectively (Table-5). 


\section{Impact of supplementation}

The mean $\mathrm{Hb}$ value $(9.19 \pm 1.93 \mathrm{~g} / \mathrm{dl})$ of anemic children was significantly different from that of non-anemic children $(12.13 \pm 0.41$ $\mathrm{g} / \mathrm{dl}$ ) before feeding of iron rich snacks (Fig. 1). The baseline $\mathrm{Hb}$ estimation revealed that 4.7 per cent subjects in the experimental group suffered from severe iron deficiency whereas 61 per cent and 34 per cent subjects suffered from moderate and mild degree of anemia respectively with an average $\mathrm{Hb}$ level of $9.19 \mathrm{~g} / \mathrm{dl}$. After the supplementation, it was found that there was significant increase in $\mathrm{Hb}$ concentration of anemic subjects; the mean $\mathrm{Hb}$ concentration being $10.16 \mathrm{~g} / \mathrm{dl}$ (Table 6).

Table.1 Sensory acceptability of developed food products on nine point hedonic scale

\begin{tabular}{|l|c|c|c|}
\hline $\begin{array}{l}\text { Sensory quality } \\
\text { Characteristics }\end{array}$ & $\begin{array}{c}\text { Chatpata namkeen } \\
\text { mix }(\mathbf{C N M})\end{array}$ & Swadisht chikki (SC) & $\begin{array}{c}\text { Chatpata namkeen } \\
\text { mix with chutney } \\
\text { (CNMC) }\end{array}$ \\
\hline Appearence & 8.40 & 7.69 & 8.13 \\
\hline Taste & 7.73 & 7.18 & 7.89 \\
\hline Flavour & 7.66 & 6.83 & 6.30 \\
\hline Texture & 8.19 & 8.03 & 8.13 \\
\hline Overall acceptability & $\mathbf{8 . 3 2}$ & $\mathbf{7 . 9 1}$ & $\mathbf{8 . 0 1}$ \\
\hline
\end{tabular}

Table.2 Nutrient composition of developed food products per $100 \mathrm{~g}$

\begin{tabular}{|l|c|c|c|}
\hline Nutrients & $\begin{array}{c}\text { Chatpata namkeen } \\
\text { mix (CNM) }\end{array}$ & Swadisht chikki (SC) & $\begin{array}{c}\text { Chatpata namkeen } \\
\text { mix with chutney } \\
\text { (CNMC) }\end{array}$ \\
\hline Moisture (g) & 3.18 & & 6.18 \\
Crude protein (g) & 6.74 & 5.15 & 7.02 \\
Crude fat (g) & 8.38 & 8.14 & 7.18 \\
Total ash (g) & 3.86 & 7.80 & 3.93 \\
Crude fibre (g) & 8.83 & 1.88 & 9.03 \\
Carbohydrate (g) & 77.84 & 6.00 & 66.66 \\
Energy value (Kcal) & 413.00 & 71.03 & 359.00 \\
Calcium (mg) & 160.00 & 386.00 & 181.00 \\
\hline
\end{tabular}

Table.3 Iron and in vitro availability of iron in developed recipes

\begin{tabular}{|l|c|c|c|c|c|}
\hline \multirow{2}{*}{$\begin{array}{c}\text { Name of } \\
\text { recipes }\end{array}$} & \multirow{2}{*}{$\begin{array}{c}\text { Total iron } \\
(\mathbf{m g} / \mathbf{1 0 0 g})\end{array}$} & \multicolumn{4}{|c|}{ In vitro iron } \\
\cline { 3 - 6 } & & $\begin{array}{c}\mathbf{p H}=\mathbf{1 . 3 5} \\
\text { Soluble iron } \\
\text { I\%) }\end{array}$ & $\begin{array}{c}\text { Ionizable iron } \\
\mathbf{( \% )}\end{array}$ & $\begin{array}{c}\text { Soluble iron } \\
\mathbf{( \% )}\end{array}$ & $\begin{array}{c}\text { Ionizable iron } \\
(\mathbf{\%})\end{array}$ \\
\hline CNM & 13.71 & 28.24 & 23.20 & 20.87 & 18.61 \\
\hline SC & 14.57 & 39.17 & 22.41 & 27.91 & 19.94 \\
\hline CNMC & 18.03 & 32.11 & 26.94 & 21.17 & 23.36 \\
\hline
\end{tabular}


Table.4 Distribution of school children for anemia as per age and sex $(n=421)$

\begin{tabular}{|c|c|c|c|c|c|c|c|}
\hline \multirow{2}{*}{ Classification } & \multicolumn{2}{|c|}{ 7-9 years } & \multicolumn{2}{|c|}{$10-12$ years } & \multicolumn{2}{|c|}{ Both } & \multirow{2}{*}{$\begin{array}{c}\text { Mean Hb } \\
\text { (g/dl) }\end{array}$} \\
\hline & $\begin{array}{c}\text { Boys } \\
(\%)\end{array}$ & $\begin{array}{l}\text { Girls } \\
(\%)\end{array}$ & $\begin{array}{c}\text { Boys } \\
(\%)\end{array}$ & $\begin{array}{c}\text { Girls } \\
(\%)\end{array}$ & $\begin{array}{l}\text { Boys } \\
(\%)\end{array}$ & $\begin{array}{c}\text { Girls } \\
(\%)\end{array}$ & \\
\hline Normal & 68.00 & 32 & 65.21 & 34.78 & 66.66 & 33.33 & $12.13 \pm 0.41$ \\
\hline Anaemic & 42.07 & 57.92 & 45.78 & 54.21 & 43.92 & 56.06 & $9.19 \pm 1.93 *$ \\
\hline
\end{tabular}

*significant difference at $(\mathrm{p}<0.05)$ level

Table.5 Age and sex distribution of anemic children on the basis of different degrees of anemia $(n=85)$

\begin{tabular}{|c|c|c|c|c|c|c|}
\hline Classification & \multicolumn{2}{|c|}{$\mathbf{7 - 9}$ years } & \multicolumn{2}{|c|}{$\mathbf{1 0 - 1 2}$ years } & Total (\%) & Mean Hb (g/dl) \\
\cline { 2 - 7 } & Boys (\%) & Girls (\%) & Boys (\%) & Girls (\%) & & \\
\hline Mild & 40.00 & 45.00 & 36.00 & 6.66 & 34.11 & 10.43 \\
\hline Moderate & 52.00 & 50.00 & 64.00 & 86.66 & 61.17 & 9.13 \\
\hline Severe & 8.00 & 5.00 & - & 6.66 & 4.70 & 6.35 \\
\hline
\end{tabular}

Table.6 Change in mean $\mathrm{Hb}$ concentration after supplementation

\begin{tabular}{|l|l|c|c|}
\hline Age & Classification & \multicolumn{2}{|c|}{$\begin{array}{c}\text { Mean Hb concentration } \\
\text { Before }\end{array}$} \\
\cline { 2 - 4 } & & $9.19 \pm 1.39$ & $10.25 \pm 1.19$ \\
7-9 year & Anemic & $12.38 \pm 0.19$ & $12.47 \pm 0.37$ \\
& Non-anemic & $9.10 \pm 1.35$ & $10.08 \pm 1.15$ \\
10-12 year & Anemic & $12.33 \pm 0.98$ & $12.42 \pm 0.98$ \\
& Non-anemic & $9.14 \pm 1.76^{*}$ & $10.16 \pm 2.08^{*}$ \\
\hline 7-12 year & Anemic & $12.35 \pm 0.48$ & $12.44 \pm 0.63$ \\
& Non-anemic & &
\end{tabular}

*significant difference between before and after the supplementation at $(\mathrm{p}<0.05)$ level

Fig.1 Change in mean $\mathrm{Hb}$ concentration of subjects

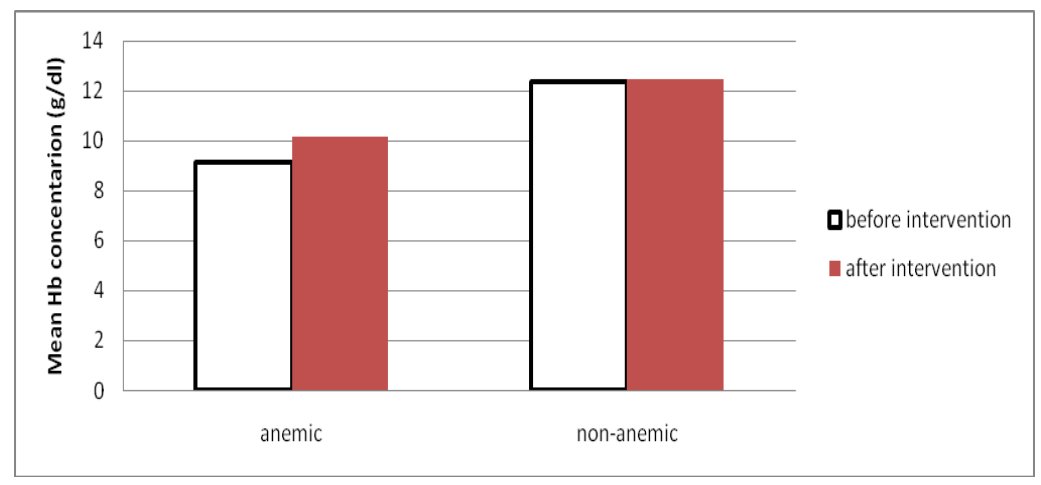


Fig.2 Impact of supplementation on different degrees of anemia among anemic children

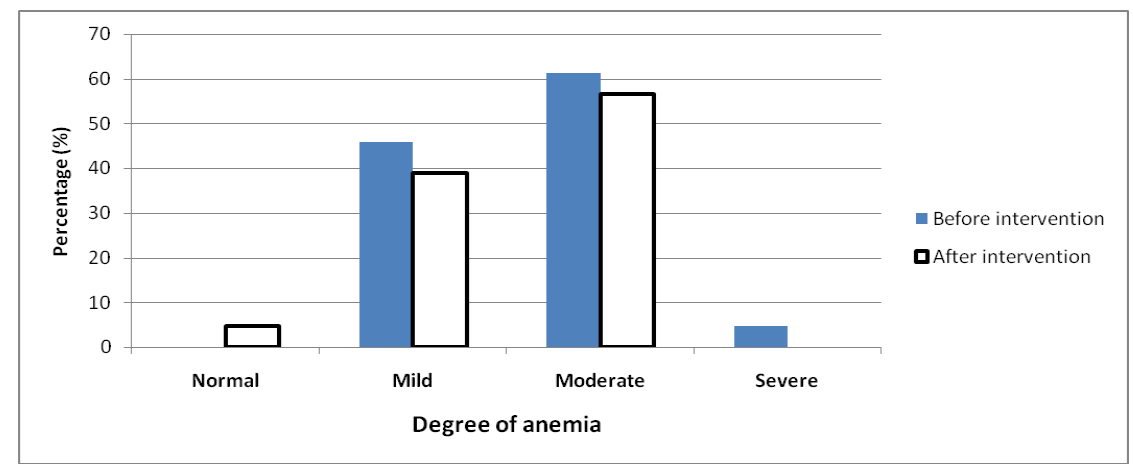

A significant reduction was observed in severe and mild degree of anemia. There was a reduction in the number of moderately anemic subjects (Fig. 2). Four subjects had also achieved a normal $\mathrm{Hb}$ concentration being more than or equal to $12 \mathrm{~g} / \mathrm{dl}$.

Iron deficiency remains a major nutritional problem among infants and young children in India. There is a high burden of anaemia in India which leads to intellectual property loss as well as reduction in work output. It may also attribute to increased burden of infectious diseases as a result of decreased immune status (Kapil, 2003). The prevalence of anaemia in school children aged 7 to 12 year was found to be 88.59 per cent in the present study with mean hemoglobin levels of 9.14 g/dl. In a study conducted under Mid Day Meal scheme in Uttarakhand, prevalence of anaemia was found to be 75.6 per cent among the primary school children in a district Tehri of Uttarakhand with 77.7 per cent of the girls and 73.4 per cent of the boys being anemic (Kushwaha et al., 2011). The prevalence of anaemia in urban slum school children of Delhi aged 5 to 10.9 yr was found to be 41.8 per cent. The prevalence of iron deficiency anaemia was significantly higher in girls (56.06 per cent) than in boys. A recent study by Sen and Kanani (2009) reported that more than two-third (68.3 per cent) girls were anemic in the age group of $9-13$ years in
Vadodara. The higher prevalence of iron deficiency anaemia as noticed in the present study may be attributed to inadequate food intake, poor stores and other nutritional deficiencies.

A large percentage of the studied children come from poor background with poor sanitation and environment that's why they are prone to infections and worm infestations. In communities with high prevalence of parasitic infections the effect of iron supplementation or fortification may be limited when it is not combined with anti helminthic therapy. Anti helminthic therapy alone improved iron status in school children in communities where parasitic infections were common (Hathirat et al., 1992). Our results also indicated the same findings when supplementation was provided after deworming 88.23 per cent children showed an improvement in hemoglobin levels.

Kushwaha et al., (2011) found that iron deficiency in Uttarakhand may be due to lack of consumption of iron rich foods, poor absorption of iron due to worm infestation and/or improper utilization of iron. Therefore the study suggested the need to make people aware about the use of locally available iron rich food items and their promotion in addition to the use of de worming tablets to prevent loss of blood due to worm infestation. 
In line with the above suggestions, daily supplementation with iron rich snacks, made of green leaves powder and cereal-pulse combination, has been made and the results shown significant impact on hemoglobin levels as well as nutritional status of school going children.

Dietary modification and diversification have advantages over other strategies in relation to compliance, long-term acceptability, costeffectiveness, risk of iron overload and a beneficial effect on the iron intake of families (Gibson and Hotz 2001), but are often criticized because they are considered too difficult to apply or because they are longterm strategies (Halimatou et al., 2009). The present study show interesting results even after short period of supplementation. Two selected iron rich snacks viz. Chatpata namkeen mix with chutney (CNMC) and Swadisht chikki (SC) were found to be superior in terms of total iron and protein content and thus a significant rise was observed in hemoglobin levels from $9.14 \mathrm{~g} / \mathrm{dl}$ to $10.16 \mathrm{~g} / \mathrm{dl}$ in the anaemic group.

The iron content of SC and CNMC falls within the range of $14-18 \mathrm{mg} / 100 \mathrm{~g}$. The reason being green leafy vegetables are rich source of iron. All the green leafy vegetables were also found to have considerable amount of ascorbic acid and tannin. In case of green leafy vegetables, the endogenous levels of enhancers and inhibitors did not found to have any impact on the availability of iron (Das et al., 2005). Also on drying the leafy vegetables, the nutrient density increases due to the loss of their high moisture content. So incorporation of mustard and spinach leaves powder in the snacks increases the iron content by several folds. Use of $100 \mathrm{~g}$ of these products daily can provide about 30-35 per cent of the daily requirements of iron for school going children.
The in vitro iron availability of the selected snacks was high; reason might be that vegan diets are high in vitamin $\mathrm{C}$. Cereals and most of the whole pulses were found to contain considerable amounts of ascorbic acid ranging from $5.5 \mathrm{mg} / 100 \mathrm{~g}$ to $51.3 \mathrm{mg} / 100 \mathrm{~g}$ (Das et al.2005).

The commonly eaten combinations, such as pulses and citrus fruits result in enhanced iron absorption and it is easy to obtain iron on a vegan diet that would meet the RDA for iron (Nair and Iyengar 2009). Another reason might be that methods of food products preparation and processing influence the bioavailability of iron. Cooking, by its thermal action, reduce the phytic acid and the hexa- and penta-inositol phosphate content thus improving the bioavailability of nonheme iron (WHO 2001).

Sensory evaluation on a nine point hedonic scale showed that both the products CNMC as well as SC were liked very much by the semitrained panel as well as by the school children so they can be successfully incorporated as breakfast or snack items at home or for community feeding to combat the problems of iron deficiency. Due to the low moisture content of these products ranging between 3 to 6 per cent, they can be stored for a number of days (Raghuvanshi and Singh, 2007).

In conclusion the results obtained in the study, with significant recovery to normal $\mathrm{Hb}$ status in more than two-third of the children, suggest that Chatpata namkeen mix with chutney and Swadisht Chikki have the potential to improve hemoglobin levels as well as protein energy malnutrition. Preventive measures for anemia control in children must be accompanied by a more holistic approach to prevent stunting and wasting by focusing on nutrition education, improved diet quality and health care measures for the children. 


\section{Acknowledgements}

Authors are Thankful to All India Coordinated Research Project (AICRP)Home Science Foods and Nutrition for the financial support in conducting the research. Thanks to Ms. Viveka Varshney for technical assistance in carrying out the study.

\section{References}

A.O.A.C. 1975. Official Methods of Analysis of the Association of Official Analytical Chemist. Washington, DC: Association of Official Analytical Chemists.

A.O.A.C. 1995. Official Methods of Analysis of the Association of Official Analytical Chemist. Washington, DC: Association of official Analytical Chemists.

Best, C., N. Neufingerl, L. V. Geel, T. V. D. Briel, and S. Osendarp. 2010. The nutritional status of school-aged children: Why should we care? Food and Nutrition Bulletin 31 (3): 400-417.

Das, P., N. Raghuramulu, and K. C. Rao. 2005. Determination of in vitro availability of iron from common foods. Journal of Human Ecology 18(1): 13-20.

Gibson, R. S., and C. Hotz. 2001. Dietary diversification/modification strategies to enhance micronutrient content and bioavailability of diets in developing countries. British Journal of Nutrition 85: S159-S166.

Halimatou, A., J. Zee, R. Dossa, and H. T. O'Brien. 2009. Effect of a nutrition education program and diet modification in Beninese adolescent girls suffering from mild iron deficiency anaemia. Ecology of Food and Nutrition 48 (1): 21-38

Hathirat, P., A. Valyasevi, N. J. Kotchabhakdi, N. Rojroongwasinkul, and Pollitt, E. 1992. Effects of an iron supplementation trial on the Fe status of
Thai schoolchildren. British Journal of Nutrition 68: 245-252.

International Institute for Population Sciences and MacroInternational. National Family Health Survey (NFHS-3), 20052006: Key Findings. Mumbai, India: International Institute for Population Sciences; 2007. Available at: www.measuredhs.com/pubs/ pdf/SR128/SR128.pdf.

Kapil, U. 2003. Prevention and control of iron deficiency anaemia amongst young children. Indian Pediatrics 40: 293295.

Kotecha, P.V.; Nirupam, S.; Karkar, P.D. 2009. Adolescent girl's anemia control programme, Gujarat, India. Indian Journal of Medical Research, 130:584589.

Kushwaha, A., R. Singh, N. Dobhal, and R. S. Raghuvanshi. 2011. Mid day meal programme in Uttarakhand: Present scenario and future prospects. Uttarakhand, India: University press, G.B. Pant University of Agriculture and Technology.

Nair, M. K., and V. Iyengar. 2009. Iron content, bioavailability \& factors affecting iron status of Indians. Indian Journal of Medical Research 130: 634645.

National Nutrition Monitoring Bureau (NNMB). 2006. Diet and nutritional status of population and prevalence of hypertension among adults in rural areas. Hyderabad, India: National Institute of Nutrition, Indian Council of Medical Research. Technical Report No. 24

Park, K. 2017. Textbook of Preventive and Social Medicine. Chapter 11, Nutrition and Health. $24^{\text {th }}$ ed. Jabalpur, India:M/s Banarsidas Bhanot: 679-680.

Pasricha, S.R., Black, J., Muthayya, S., Shet, A., Bhat, V., Nagraj, S., Prashanth, N.S., Sudarshan, H, ANN Biggs, B. and 
Shet, A.S. 2010. Determinants of anaemia among young children in rural India. Pediatrics. 126(1),e140-9.

Raghuramulu, N., M. K. Nair, and S. Kalyansundaram. 2003. A manual of laboratory techniques. 2nd ed. Hyderabad: National Institute of Nutrition.

Raghuvanshi, R.S.and Singh R. 2007. Development and storage stability of $\beta$ carotene rich products using green leafy vegetable powder. Journal of EcoFriendly Agriculture, 2(1):59-62.

Rao, B. S., and T. Prabhawathi. 1978. An in vitro method for predicting the bioavailability of iron from foods. American Journal of Clinical Nutrition 31: 169-175.

Sen, A., and S. J. Kanani. 2009. Impact of iron-folic acid supplementation on cognitive abilities of school girls in Vadodara. Indian Pediatrics 46: 137143.

Snedecor G. W., and W. G. Cochran. 1967. Statistical methods. Calcutta: Oxford and IBH Publishing Co.

Tennnat, G. B., and D. A. Greenman. 1969. Determination of iron in solution containing iron complexes. Journal of Clinical Pathology 22 (3): 301-303.

WHO. 1989. DeMaeyer EM, Dallman P, Gurney JM, Hallberg L, Sood SK, Srikantia SG. Preventing and controlling iron deficiency anaemia through primary health care: a guide for health administrators and programme managers. Geneva: World Health organization; 1989. p. 8-9.

WHO/CDC. 2008 (a). Worldwide prevalence of anaemia 1993-2005. WHO Global database on anaemia. Geneva: World Health Organization. (http://whqlibdoc.who.int/publications/ 2008/9789241596657_eng.pdf).

WHO, UNICEF, UNU. 2001. Iron Deficiency Anaemia Assessment, Prevention and Control: A Guide for Programme Managers. 1st Edition. Geneva: World Health Organization.

\section{How to cite this article:}

Rita Singh Raghuvanshi, Pushpa Shukla and Rashmi Singh. 2020. Impact of Food based Supplementation on Iron Nutrition of School Children. Int.J.Curr.Microbiol.App.Sci. 9(11): 1177-1186. doi: https://doi.org/10.20546/ijcmas.2020.911.137 